報文

(30)

\section{反応を伴なう固一液系擋拌における物質移動}

\section{遷移的飽和度亡擋拌 反応係数"}

永田進治林.山口㦑林

\section{1. 緒 言}

著者らはさきに広範囲の実験条件につき結晶の擋拌液 に対する溶解速度を測定して固体粒子と液体間に物理的 拡散のみが行なわれる場合の固一夜系擋拌における物質 移動について報告しだ〉。すなわち物質移動係数に及ぼ す固, 液の物性の影響, 装眉拡大の基準, 擋拌速度上年 の効果などを明らかにし，一連の幾何学的に相似な擋拌 装置を用いる場合につき任意の固－液の組合わせに対す る物質移動データの推算を可能にした。

しかしながら擋拌操作は異相系の液相反応操作の補助 としてきわめて広く適用され，また逆に異相系反応の動 力学は必ずその反応を進めるための接触装置の機能とも 密接に関連する。したがって反応を伴なら異相系擋拌に おける物質移動は擋拌操作の研究対象としてる，異相系 反応の基礎的研究の対象としても化学工学上重要であ る。

純化学反応の抵抗と物理的拡散の抵抗との大きさの比

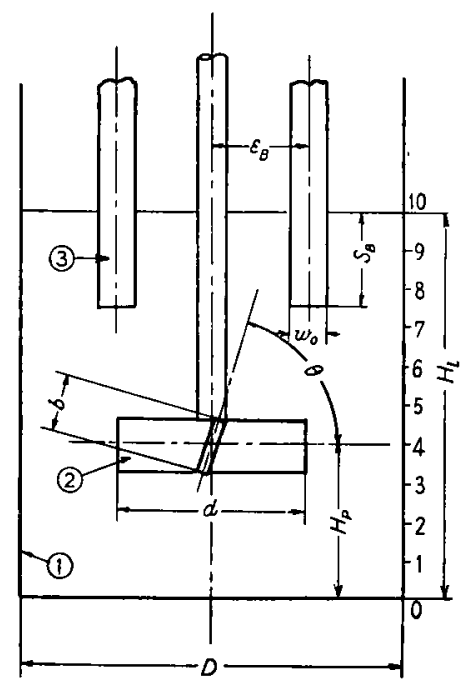

(1) Vessel, (2) Impeller, (3) Baffle plates.

Fig. 1 Diagram showing the agitation equipment and the baffled conditions.

* 昭和 34 年 12 月 9 日受理, 昭和 34 年 4 月 3 日化学工学協会第 24 年

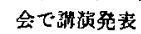

** 京都大学工学部化学找学教室
によって区別される次の各種の場合に見かけの反応速度 に及ぼす擋拌の効果がどのよ5になるかを調べることは きわめて興味深い。

（1）拡散抵抗支配の昜合 総括反応速度が物理的拡 散の抵抗のみによって支配される場合で，擋拌を強化す ればするはど物質移動は促進ざれる。

（2）拡散と化学反応の抵抗とが対比的な大きさであ る場合 総括反応速度が拡散と化学反応の抵抗の两者に よって支配される場合であって擋拌は効果的であるが (1) の場合ほどには著しくない。

（3）化学反応抵抗支配の場合 総括反応速度は擋拌 速度をいかに增大してる变化しない。

著者らはこれらのうちすでに（1）の場合を明らかに したことを上に述べたが，本報ではこれらのすべての場 合を総括する一般の反応速度式を示し，総括反応速度と 擋拌強度との関係，扣よび上記のおのおのの場合が実現 される理論的条件を誘導する。また反応抵抗と拡散抵抗 との大きさの比が，適当な值で実験条件の選び方によっ てあらゆる場合が実現できる無水フタル酸と無水安息香 酸の加水分解反応の実例によって，理論と実験結果とを 比較対照しつつこれらの一致を示す。

なお著者らは“覀移的飽和度”と“異相系反応に対す る擋拌反応係数”の概念を新しく導入する。これらは異 相系の液相反応における擋拌の效果を定量的に示す值 で，後者によって必要な摚拌速度が決定される。

\section{2. 実験装置むよひ実験方法}

（a）実験装置 擋拌槽は内径 $D=10 \mathrm{~cm}$ の扁平底 面円簡形ガラス槽で装置各部の寸法を表わす記号を Fig. 1 に示す。液深さ $H_{l}=D$ とした。擋拌巽は櫂形 4 枚羽根, 翼長 $d=5 \mathrm{~cm}$, 翼幅 $b=1.5 \mathrm{~cm}$, 翼角度 $\theta=$ $75^{\circ}$ を用いた。翼取付高さ $H_{P}=4 \mathrm{~cm}$ である。無水フタ ル酸には邪魔板なし，無水安息香酸には軽分散質用邪魔 板付 ${ }^{24}$ を用いた。幅 $w_{0}=1 \mathrm{~cm}$ の SUS-12 ステンレス 鋼板 2 枚を図のことく対称的に $\varepsilon_{B}=2.5 \mathrm{~cm}, S_{B}=2.5 \mathrm{~cm}$ で取付けた。反応生成物の濃度変化を追跡するための液 の電気伝導度测定装淔は前報

（b）実験試料 固体試料としては水に溶解したの ち加水分解して電解質となる酸無水物の結晶を選び，水 
に対する溶解度が小で溶解速度が加水分解 速度にほぼ匹敵する反応条件を満たすこと ができる無水フタル酸と無水安息香酸を用 いた。前者は工業用をべンゼンで，後者は 市肘の化学用をフルコールで反䃌再結晶し て純度を高めた後，擋拌下に晶析させて柱 状とした。結晶の平均粒径は前報”同様, 球相当直径 $d_{p}$ で示す。電気伝導度が $1 \times$ $10^{-6} \mathrm{mho}$ 末満の純水を用いた。水は溶媒で あると共に加水分解反応の一成分でもあ る。

（c） 実験方法 摚拌槽に水 $785 \mathrm{cc}$ を 仕込み $25.0 \pm 0.1^{\circ} \mathrm{C}$ 一定に調温して, 液 が定常擋拌状態洼幸した後, 酸無水物の結

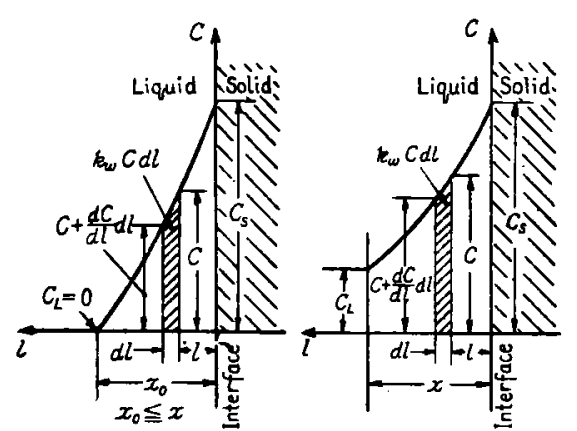

(a) Diffusion rate controlling.

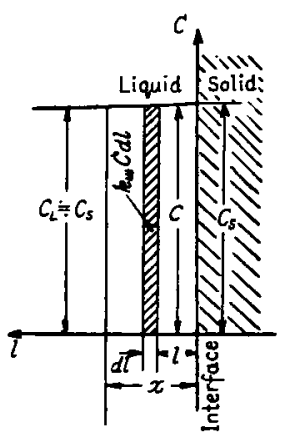

(c) Chemical reaction rate controlling.

Fig. 2 Diagram showing the concentration gradient at the liquidsolid interface after a steady state is attained.

晶を投入する。結晶はまず水に溶け，引続いて加水分解 して酸となる。生成する酸の水溶液の電気伝導度を連続 的に測定して生成量の時間的変化を追跡した。

なおこれらの酸無水物は加水分解速度が迤いから溶解 した後なお暫時末反応のままて擋拌液本体中に残ってい る。したがって，擋拌液の一部をガラス滤過器を通して 速やかに結晶より分離し，その後の酸の生成量の時間的 变化を追跡すれば加水分解の反応速度定数が 決定せら れ、またその反応が完了したときの平衡浱度と分離した 瞬間の濃度との差から分蜼時の液本体における未反応の 酸無水物の溶解量が求められる。

\section{3. 反応を伴なう固－液系媄拌の物算移動}

固一夜系は擋拌速度によって界面秥が変化しないか ら，異相系擋拌のうちでは最る基本的な系と言える。ま た固体が触媒であるか反応物質であるかによって反応速 度式の形むやや異なるか，前者で表面反応の場合を除け ばすへてて本報における実験例の上うに固体の反底物質が 液汇溶解しつつ反応する場合に準じて取り扱える。

次にこのような固一液系反応の物質移動について説明 し上5。定常擋拌の状態に達した水中に酸無水物の結晶 を投入すると，まずはじめは酸無水物が結晶表面から非 定常桩散の状態て壋拌液本体へ向かって溶解する過程が あると考之られる。しかも酸無水物は拡散しつつ次第に 次のことく加水分解の反応によって酸に転じていく。

$$
\mathrm{CO}_{\mathrm{CO}}^{\mathrm{CO}}>\mathrm{O}+\mathrm{H}_{2} \mathrm{O} \rightarrow \mathrm{COOH}_{\mathrm{COOH}}^{\mathrm{C}}
$$

その場合液相における反応そのむのは均一系の 2 次反応 で一般にその速度は次式で与えられる。

$$
r=k C_{w} C
$$

*此重差の小なる固一液系ではと洁 $K \propto D f$ の成釈が成立する（前

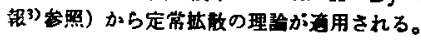

しかし水が酸無水物掞よび生成する酸に比して大過剩 に存在する場合は $C_{w}$ 一定で (1) 式の逆反応る無視さ れ見か汗上は1次反応となる。

$$
r=-d C / d \theta=k_{w} C
$$

時間が経過すれば次第に界面近傍における濃度分布が 変化して液本体における酸無水物の㬊度が增加する，そ れ応じて総括反応速度が增大するが，逆化执散に対す る推進力は堿少するので, やがてこれらが平衡に達して 物質移動が定常状態になる。Fig. 2 はこのよ5な状態 になったときの酸無水物の濃度分布を示す。(a) は液量 がきうめて多量であるか，拡散抵抗が反応抵抗に比して 大なる場合，すなわち拡散律速の場合であって総括反応 速度は次式で示される[媵述 (24) 式照]。

$$
R=K A C_{3}
$$

無水フタル酸および無水安息香酸は水汶対する溶解度 がきかめて小で溶解の進行に伴な $5 . A$ の変化を無視し 5 る範囲で $R$ 一定となる。(b) 恓両抵抗の大きさが ほ济匹敵する場合を示す。桩散境膜内での反応量は液量

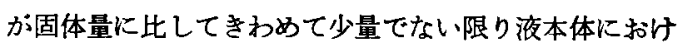
る反応量に比して小で無視してよいから $R$ は次式で与 えられる。

$$
R \doteqdot k_{\text {wo }} V C_{L}
$$

定常拡散状態では $C_{L}$ は一定であるからやはり $R$ は 一定となる。(c) は反応抵抗が搪散焎抗に比して大であ るか界面皘が大なる場合で夜本体が未反応の酸無水物で 飽和されて完全に反応律速になった模様を示す。

で $R$ は一定である。

$$
R=k_{w} V C \text {, }
$$

以上いずれの場合る総括反応速度が一定で見かけ上は 擬需次の反応機構が示され反応速度曲線は等分目盛の方 眼紙上直線となる(後述 Fig. 3 参照)。

ところで一般に上記のいずれの場合に対しても，総括 反応速度 $R$ は定常桩散の理論*に基つけけば，次式で示 


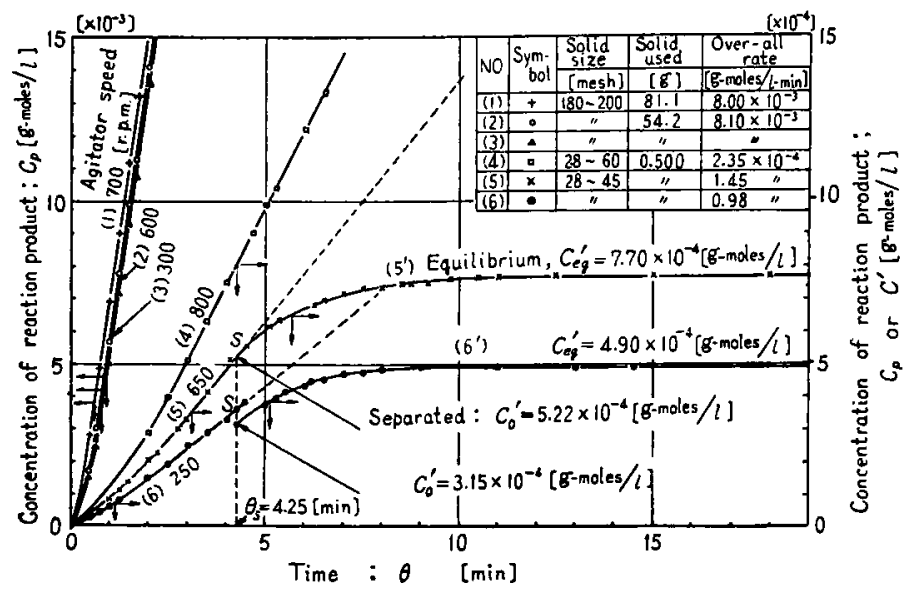

Fig. 3 Reaction rate curves showing the hydrolysis rate of phthalic acid anhydride-water agitation system.
$C^{\prime}$ との差 $C=C_{\text {eq }}{ }^{\prime}-C^{\prime}$ が末反応の 残留無水フタル酸の濃度を与兄る。 この加水分解は上述のごとく水過鄱 の状態で行なわれるから $C$ と $\theta$ と の関係は（3）式の積分形：

$$
-2.303 \log C=k_{w} \theta+I
$$

で表わされる。C を $\theta$ に対して片 対数方眼紙偟点緅すれば Fig. 6 の ことくなり，その勾配から $k_{w}$ はそ れぞれ $N=650$ および 250r. p.m. に対し 0.575 および 0.620 (平均値 は 0.598) [1/min] と求められる。 ちなみに I.C.T. には $k_{w}$ の值と して

$k_{1 p}=0.607[1 / \mathrm{min}]\left(25^{\circ} \mathrm{C}\right)$
される゙。

$$
R=A \beta K\left\{C_{\mathrm{s}}-\left(C_{L} / \cosh \gamma\right)\right\}
$$

ここに $K$ は物質移動係数で $D_{f} / x$ に等しく， $\beta=\gamma / \tanh \gamma, \gamma=\alpha x, \alpha=\left(k_{w} / D_{f}\right)^{1 / 2}$

であって， $\boldsymbol{\beta}$ は Hatta 数 (物質移動の反応係数) と呼 ばれている。 $V / A=0$ で表わせば次の関係が成り立つ,

$$
C_{L}=C_{\mathrm{s}} /(\cosh \gamma+a v \sinh \gamma)
$$

\section{4. 実 験 結 果}

（a）総括反応速度と摚拌速度との関係 Fig. 3 は 無水フタル酸一水系の加水分解速度曲楾を示す。初めの 過渡状態を経たのちは $C_{p}$ と $\theta$ との関係は直線となっ ている。たとえば曲線（5）は28４5 mesh の無水フタ ル酸 $0.5 \mathrm{~g}, N=650 \mathrm{r} . \mathrm{p} . \mathrm{m}$. のときの結果で約 3 分後に 物質移動が定常状態に達し， $R / V$ の値はこの直楾部分 の傾斜より $1.45 \times 10^{-4}[\mathrm{~g}-\mathrm{moles} / l \cdot \mathrm{min}]$ と求められる。 同様にして種々の条件で $R / V$ の値を測定して $N$ に対 して対数方眼紙上に点緅すると Fig. 4 のことくなる。

Fig. 5 は無水安息香酸に対する同粎の結果である。

（b）酸無水物の液本体における溶解量 上述の実 験例について， $\theta=4.25 \mathrm{~min}$ を経たとき，すなわち完全 に定常抬散状態に達した後，擋拌液本体の一部をガラス 渽過器を通して分離し, 分離液中の加水分解量の時間的 変化を追跡すれば Fig. 3 曲線 $\left(5^{\prime}\right)$ の結果が示される。 平衡濃度 $C_{e q}{ }^{\prime}=7.70 \times 10^{-4}$ と分離したときの濃度 $C_{。}^{\prime}$ $=5.22 \times 10^{-4}$ との差

$$
C_{L}=C_{e q}{ }^{\prime}-C_{0}{ }^{\prime}=2.48 \times 10^{-4}[\mathrm{~g}-\mathrm{moles} / l]
$$

が然皮フタル酸の溶解量である。

（c）反応速度定数の決定 ふたたび上述の例につ いて， $C_{e q}{ }^{\prime}$ と分離液の任意の㭙間 $\theta$ のときの酸の濃度
と示されている。

（d）酸無水物の铇和湜度 酸無水物の水に対する 溶解度 $\left(C_{s}\right)$ は過剩の酸無水物を投入乙て液本体を飽和 状態にして上述の方法によって直接湘定することもでき るが, その反応律速の状態の総括反応速度 $(R / V)$ の測 定值から（6）式の变形である次式の関係によって間接 的に求められる。

$$
C_{s}=R / k_{w} V
$$

この状態を実現するために必要な投入量は次のように して推算される。（8）式において擋拌速度によって变化 する値は $\gamma$ のみで， $\alpha v=1$ なる条件が满たされる場合 常に $C_{L}=C$ ，となるからこのよ5K実験条件を選べば 擋拌速度のいかんにかかわらず常に反応律速となるわけ である。180 200 mesh $\left(d_{p}=0.079 \mathrm{~mm}\right)$ の無水フタル 酸を用いる場合，粒子の表面積を球相当直径 $d_{p}$ の球 の表面榣に等しいと拈いて，払散係数 $D_{f}=7.75 \times 10^{-6}$ $\left[\mathrm{cm}^{2} / \mathrm{sec}\right]$ の値*を用いると，

$$
\begin{aligned}
A & =\pi d_{p}^{2}\left\{W /(\pi / 6) \rho_{s} d_{p}^{3}\right\}=6 W / \rho_{s} d_{p} \\
& =6 W /\left(1.46 \times 7.9 \times 10^{-3}\right)\left[\mathrm{cm}^{2}\right]
\end{aligned}
$$

であるから

$$
\alpha v=\sqrt{\frac{k_{w}}{D_{f}}} \frac{V}{A}=\sqrt{\frac{0.598}{7.75 \times 10^{-6} \times 60}} \times \frac{785}{A}=\mathrm{I}
$$

の関係を満たす $W$ の値は $54.2 \mathrm{~g}$ となる。

Fig. 3 曲線 (2) および (3) は 180〜200 mesh の微 粉末 $54.2 \mathrm{~g}$ を用いたとさの実測值を示す。定常拡散に 達するまでの時間が異なるために, 両曲線は重なり合っ ていないが，定常に達した後の曲線の勾配はほぼ等しく

* Wilke の方法6)およ゙ Othemer の方法5比よる推算便，それぞ れ $7.78 \times 10^{-6}$ およひ $7.72 \times 10^{-6}$ の平均である。後述の無水安息香 酸の $D_{f}$ る同棣の方法に上る推算值である。 
$R / V=8.10 \times 10^{-3}[\mathrm{~g}$-moles $/ l \cdot \mathrm{min}]$ であ る。この結果は反応律速の状態に達したこ とを示すのであるが，さらにこれを確かめ るために同じ無水フタル酸試料の 1.5 倍量 を用いて $N=700$ r.p.m. としたときの結 果が曲線 (1) である。 $R / V=8.00 \times 10^{-3}$ [g-moles $/ l \cdot \mathrm{min}]$ で実験誤差の筝囲内で一。 致している。

この值を (12) 式に入れると

$C_{\mathrm{s}}=8.10 \times 10^{-3} / 0.598 \times 1=1.35 \times 10^{-2}$

[g-moles/l] (15)

と求められる。

\section{5. 要移的铇和度}

著者らは酸無水物の撹拌液本体に打ける 浀度 $\left(C_{L}\right)$ とその飽和濃度 $\left(C_{s}\right)$ との比 [Fig. 2 および (8) 式参照] を“遷移的飽 和度”と呼ふことにする。この比を $\Phi$ と おけばその值は次式で示される。

$$
\Phi \equiv C_{L} / C_{s}=1 /(\cosh \gamma+\alpha v \sinh \gamma)
$$

Фの値は異相系擋拌における物質移動に 対する摚拌効果を示す一つの尺度となり， Фが1に近ければあはやその系に対して擋 拌を強化することは無意味である [Fig. 2 (c) 参照。ところで $\Phi$ の值は上述のよう にして $C_{L}$ と $C$ 。の值を測定して (16) 式 により直接求めることもできるが， $\Phi$ は，

$$
R=k_{w} V C_{L}=k_{w} V C, \Phi
$$

と総括反応速度に関係しているから， $R / V$ の測定值から間接的に，

$$
\Phi=(R / V) / k_{w} C
$$

と求められる。Fig. 3 曲線 (5) に示す実 験例については,

$$
\begin{aligned}
\Phi=\frac{R / V}{k_{w} C,} & =\frac{1.45 \times 10^{-4}}{0.598 \times 1.35 \times 10^{-2}} \\
& =0.0179
\end{aligned}
$$

直接液本体の一部を分離して測定した $C_{L}$ の值からは,

$$
\Phi=\frac{C_{L}}{C .}=\frac{7.70 \times 10^{-4}-5.22 \times 10^{-1}}{1.35 \times 10^{-2}}=0.0184
$$

となり，両者はよく一致する。なお $N=250$ r. p. m. の 実験結果 [Fig. 3 曲線 (6) 参照] では (19)および (20) 式による $\Phi$ の值の計算結果はそれぞれ 0.0121 扣よび 0.0129 となった。

その他の実験結果についても $R / V$ と $N$ との関係を

\begin{tabular}{|c|c|c|c|c|c|}
\hline \multirow[b]{2}{*}{ No. } & \multirow[b]{2}{*}{ Symbol } & \multicolumn{3}{|c|}{ Phthalic acid anhydride crystal } & \multirow{2}{*}{$\begin{array}{l}\text { Tempera- } \\
\text { ture }\end{array}$} \\
\hline & & -Used & $\begin{array}{c}\text { Sieved } \\
\text { range }\end{array}$ & $\begin{array}{l}\text { Particle } \\
\text { size }\left(\alpha_{\rho}\right)\end{array}$ & \\
\hline & & {$[B]$} & [mesh] & $(\mathrm{mm})$ & {$\left[0^{\circ} \mathrm{C}\right]$} \\
\hline $\begin{array}{l}\text { (1) } \\
\text { (2) } \\
\text { (3) } \\
\text { (4) }\end{array}$ & $\begin{array}{l}\dot{\bullet} \\
\dot{0} \\
+\end{array}$ & $\begin{array}{l}0.500 \\
0.300 \\
0.500 \\
" 1\end{array}$ & $\begin{array}{l}10 \sim 16 \\
16 \sim 28 \\
28 \sim 45 \\
28 \sim 60\end{array}$ & $\begin{array}{l}1.59 \\
0.928 \\
-\end{array}$ & $\begin{array}{c}25.0 \\
" \prime \\
26.5\end{array}$ \\
\hline \multirow[t]{2}{*}{ (5) } & D & 54.2 & $180 \sim 200$ & 0.097 & 25.0 \\
\hline & $\mathbf{x}$ & 81.1 & " & $"$ & " \\
\hline
\end{tabular}
$\Phi$ と $N$ との関係に換算して Fig. 4 および Fig. 5 に

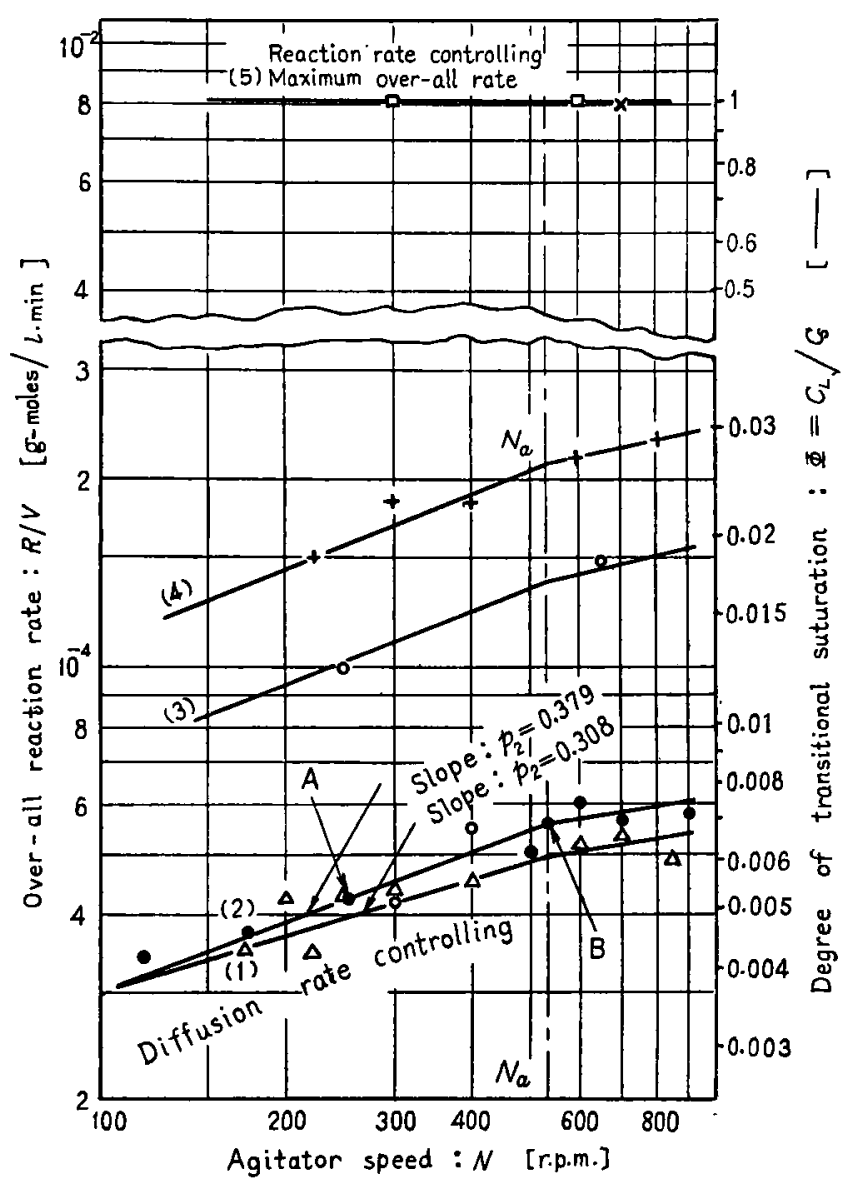

Fig- 4 Diagram showing the effect of agitation upon the over-all reaction rate of hydrolysis and the degree of transitional saturation $(\emptyset)$ in phthalic acid anhydride-water system.

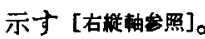

\section{6. 搅拌反応係数}

総括反応速度を表わす（7）式に（8）式を代入して变 形すれば次式が導かれる。

$$
R=\sqrt{k_{w} D_{f}} A C_{s}\left\{1+-\frac{2}{\left(\frac{a v+1}{a v-1}\right) e^{2 \gamma-1}}\right\}
$$

（21）式において，擋拌によって变化する值は $r=\alpha x の$ 


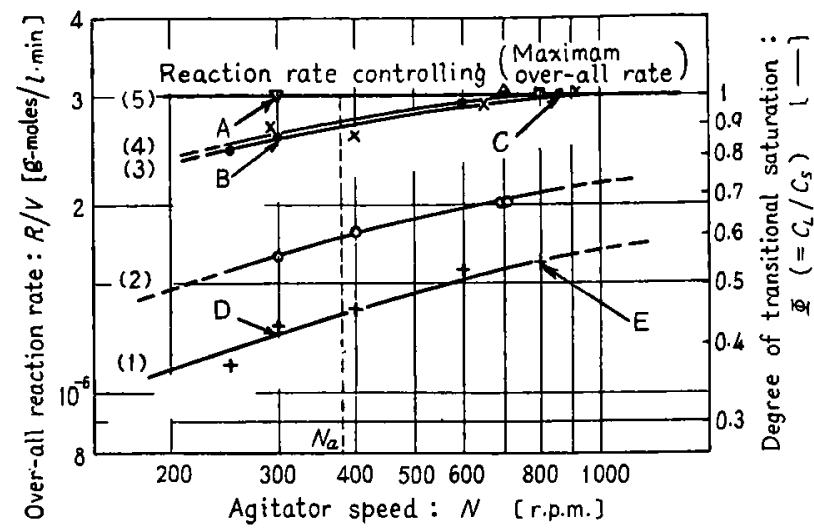

Fig. 5 Diagram showing the effect of agitation upon the overall hydrolysis reaction rate' and the degree of transitional saturation $(\Phi)$ in benzoic acid anhydride-water reaction system.

\begin{tabular}{|c|c|c|c|c|}
\hline NO. & Symbol & $\begin{array}{l}\text { Sieved range } \\
\text { [mesh] }\end{array}$ & $\begin{array}{c}\text { Portticle diameter } \\
\alpha_{0}[\mathrm{~mm}]\end{array}$ & $\begin{array}{c}\text { Amount of particles used } \\
{[\mathrm{B}]}\end{array}$ \\
\hline (1) & + & $28 \sim 35$ & 0.590 & 0.500 \\
\hline (2) & 0 & $35-45$ & 0.390 & $"$ \\
\hline (3) & $x$ & $28-45$ & 0.568 & 1.500 \\
\hline (4) & - & $35 \sim 45$ & 0.390 & 2.000 \\
\hline (5) & $\begin{array}{l}\Delta \\
0\end{array}$ & $28 \sim 60$ & $\begin{array}{c}0.480 \\
11\end{array}$ & $\begin{array}{l}2.500 \\
3.000\end{array}$ \\
\hline & $\nabla$ & $45-60$ & $0.2 \dot{85}$ & 4.000 \\
\hline
\end{tabular}

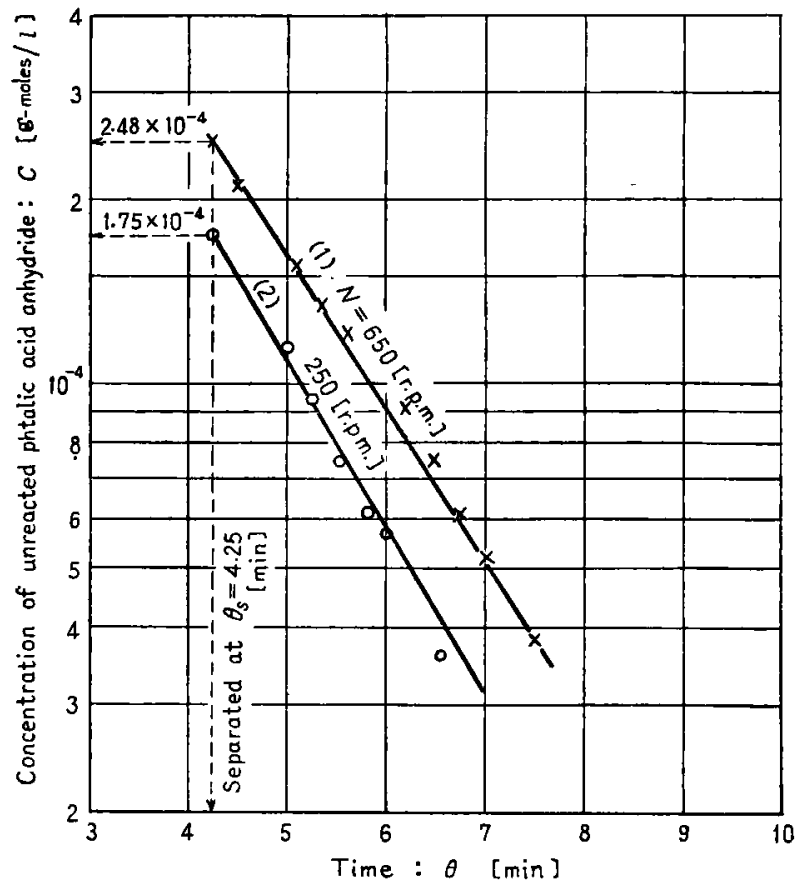

Fig. 6 Diagram used for determining the hydrolysis reaction rate constant of phthalic acid anhydride.
みである。よっていま

$$
\left\{1+\frac{2}{\left(\frac{\alpha v+1}{\alpha v-1}\right) \overline{e^{2 \tau}-1}}\right\} \equiv \Psi
$$

とおけば， $\Psi$ は総括反応速度に比例する值で あるから， $\Psi \sim 1 / \gamma$ の関係によって総括反応 速度に及ぼす擋拌の好果が示される。著者ら はこの $\Psi$ を“擋拌反応係数”とよふことに する。

また反応抵抗と拡散抵抗との大ささの比 $D_{f} / k_{v}$ および液量と界面積との比 $V / A$ すな わち反応条件によって決まる值

$$
a v=\left(k_{w} / D_{f}\right)^{1 / 2}(V / A)
$$

を助変数として， $\Psi$ と $1 / \gamma$ との関係につき 数値計算を行なって結果を Fig. 7 に図示し た。

次に $\alpha v$ の特定の值によって実現される特 別の場合について考察してみよう。

（a） $a v \rightarrow \infty$ の場合 付帯条件として $1 / \gamma \geqq 5$ を入れると，Fig. 7 曲楾（1）からむ 明らかなことく次の関係がある。

$$
\Psi=1 / \gamma=K /\left(k_{w} D_{f}\right)^{1 / 2}
$$

（23）式の関係を（7）式に入れると $R$ は次 式で示される。

$$
R=K A C_{s}
$$

これは反応速度がきわめて大なる場合 $\left(k_{x 0} 》\right.$ $\left.D_{f}\right)$ であるか液量がきわめて多い場合（V》) A）で言うまでもなく拡散律速となることを 示している。

(b) $1 / \boldsymbol{\gamma} \rightarrow \infty(\boldsymbol{\gamma}=\boldsymbol{a x} \rightarrow 0)$ の場合 これ は $x$ の值がきわめて小となる条件，すなわ ち擋拌がきわめて強烈な場合に実現される。 $r$ が零に近つくときの $\Psi$ の極限值を取れば, (22) 式は

$$
\Psi=\alpha v=\left(k_{w} / D_{f}\right)^{1 / 2}(V / A)
$$

となる。（25）式を（21）式に入れると， $\alpha 0$ の值ついかんにかかわらず $R$ は次式の形に なる。

$$
R=k_{10} C_{\mathrm{a}} V
$$

これは擋拌速度を十分に大にすれば， $x$ の值 が零に近つき払散抵抗がきわめて小となり総 括反応速度がけっきょく反応抵抗のみによっ て支配される状態に到達することを示す。反 応条件によって決まる av の種々の値につい て，反応速度支配の状態となる場合の $\boldsymbol{\Psi}$ の 極限值は Fig. 7 から容易に読みとられる。 
(c) $a v=1\left[\left(k_{w}\right)\right.$ $\left.\left.D_{f}\right)^{1 / 2}=\boldsymbol{A} / \boldsymbol{V}\right]$ の場合 この関係を（22）式に 入れると の值のいかん にかかわらず, 常に $\Psi=$ 1 となり (21) 式は

$$
\begin{aligned}
R & =\left(k_{w} D_{f}\right)^{1 / 2} A C_{s} \\
& =k_{v} C_{s} V
\end{aligned}
$$

となる。すなわち擋拌速 今 度のいかんにかかわらず 固体粒子が液中に分散し てさえ打れば，反応抵抗 支配となる。これは液量 に比して固体の有効表面 秷がきわめて大であるか または $k_{w}$ の値が $D_{f} K$ 比して十分に小なる場合 に実現され，液本体が反 応物質で飽和された状態 である。

(d) (a), (b), (c) 以

外の場合ここれは拡散抵抗と反応抵抗とが対比的な大 きさの場合であって，払散と化学反応の両抵抗が総括反 応速度を支配する異相系反応独特の反応型式である。

\section{7. 総括反底速度と摚拌速度との関係}

著者らはさきに厷範用の実験条件につき結晶の擋拌液 に対する溶解速度を測定して擋拌速度 $N$ の $N_{f}$ (粒子 浮遊限界擋拌速度) と $N_{a}$ (空気吸込限界摚拌速度) と の間の範冊に対し次の実験式を得だ”。

$$
\begin{aligned}
\frac{D}{x}=S h= & .60 \times 10^{12}(R e)^{p_{2}}\left(S_{c}\right)^{9}\left(D_{f}^{2} / D^{3} g\right)^{0.627} \\
& \times \delta^{3.08} A^{-2.82}\left(\Phi_{s} / \pi\right)^{-1}
\end{aligned}
$$

ここに指数 $p_{2}$ および $q$ はそれぞれ次式で与えられる。 $p_{2}=0.0802\left(D^{3} g / \nu^{2}\right)^{0.077}\{\log (\Delta+0.043)+1.35\}$

$$
\times 10^{-13.5 \delta}
$$

$q=-14.4 \delta+1.84 \Delta^{0.116}$

$$
\delta=d_{p} / D, \Delta=\left(p_{\mathrm{s}}-p_{l}\right) / p_{l}
$$

(28) （30）式に上って有効执散境膜厚さ $x$ と擋捍速度 との関俰がわかる。 $x$ は $=\alpha x$ と $r$ に比例する量であ $\eta$ ，一方擋拌反応俰数 $\Psi$ は総括反応速度 $R$ に比例与 る量である。したがって と $1 /$ と との関保 (Fig. 7 参 照）に上って総括反応速度 $R$ と摚拌速度との関係を利 ることができるわけである。

次に反応条件によって決まる $\alpha v$ の値の種々の場合に つき $\Psi \sim 1 / \gamma$ 因を用いて，実験結果と理論式とを比較
対照しつつ総括反応速度に及ぼす擋拌速度の影響を明ら がしよう。

7.1 扩散抵抗支配の場合（(a)の場合）たと爷ば Fig. 4 曲線（2）は粒径が 16 28mesh の無水フタル酸 の少量を用いた場合の結果を示す。この場合（13）およ び（14）式によって $\alpha v$ の値を算出すると 2110 となる。 また $N=250$ r. p.m. について (28) (30) 式によって $D / x$ の值を推算すれば $4.03 \times 10^{-3}$ となるから $1 / r$ の 值は11.3となる。同様に $N=530$ r.p.m. では $1 / \tau=$ 15.3 となる。これらの値は Fig. 7 では B および C 点 に相当し,この図から汪ぼ完全な拡散律速の範囲にある ことがわかる。な怙 $\Psi$ の值はそれぞれ $\Psi_{B}=11.3 ， \Psi_{C}$ $=15.3$ で総括反応速度の実測值 [Fig. 4 曲線 (2) 点 $\mathrm{A}, \mathrm{B}$ 参照] $(R / V)_{B}=4.15 \times 10^{-5}$ および $(R / V)_{C}=$ $5.55 \times 10^{-5}[\mathrm{~g}$-moles $/ l \cdot \mathrm{min}]$ である。それらの比はそれ ぞれ $\Psi_{B} / \Psi_{C}=0.739$ および $(R / V)_{B} /(R / V)_{C}=0.748$ と よく一致している。また Fig. 7 から $1 / \gamma \rightarrow \infty$ Kおけ る $\Psi$ の值 $\Psi_{\max }=2110$ と読みとられ， $R / V$ の最大值 $(R / V)_{\max }=8.10 \times 10^{-3}[\mathrm{~g} \cdot \mathrm{moles} / l \cdot \mathrm{min}]$ である。よっ $\tau \Psi_{B} / \Psi_{\max }=5.35 \times 10^{-3}, \quad(R / V)_{B} /(R / V)_{\max }=5.12$ $\times 10^{-3}$ とこれまたよく一致している。なお $\Psi_{B}=11.3$ の值を（21）式に代入して $(R / V)_{B}$ の値を推算すれば $4.31 \times 10^{-5}$ となる実測值に近い。

さらに Fig. 4 曲線（2）は（29）式で与えられる $p_{2}$ の推算値 0.379 の公配で画いた計算線であるが実測值の 
勾配とよく一致している。この結果によっても実験と理 諭との一致はもとより払散抵抗支配の反応系であること の推論が碓かめられたわけである。

\section{2 払散およひ反応の両抵抗の大きさが対比的であ} 了場合（(d) の場合） Fig. 5 曲線（1） は 28 35 $\operatorname{mesh}\left(d_{p}=0.590 \mathrm{~mm}\right)$ の無水安息香酸 $0.500 \mathrm{~g}$ を用い たときの $R / V$ の実測值と $N$ との関係を示す。 $N=300$ r.p.m. では $R / V=1.28 \times 10^{-6}[\mathrm{~g} \cdot \mathrm{moles} / \mathrm{l} \cdot \mathrm{min}]$ で Fig. 5 の D 点に相当する。この場合 $a v=139$ で, $1 / \gamma$ の值はこの㶵水安息香酸試料 $\left(p_{\mathrm{s}}=1.20 \mathrm{~g} / \mathrm{cm}^{3}\right)$ と比重, 粒径のほぼ等しいフロトン酸結晶 $\left(\rho_{s}=1.16 \mathrm{~g} / \mathrm{cm}^{3}, d_{p}\right.$ $=0.590 \mathrm{~mm}$ ）の同じく軽分敬質用邪魔板付の檔拌装置 による溶解速度の湘定値から推算してみると，

$$
\begin{aligned}
& x=\frac{D_{f e}}{K}=D_{f c} /\left(\frac{R / V}{C,}-\overline{A_{c}} / \bar{V}\right) \\
& =9.71 \times 10^{-6} /\left(\frac{2.47 / 1000 \times 60}{94.0 \times 10^{-3} \times 43.8 / 785}\right) \\
& =1.47 \times 10^{-3}[\mathrm{~cm}] \\
& \frac{1}{\gamma}={ }_{-}\left(k_{w} / D_{f}\right)^{1 / 2-2}=1 /\left(\sqrt{\frac{0.0197 / 60}{5.87 \times 10^{-6}} \times 1.47 \times 10^{-3}}\right) \\
& =115
\end{aligned}
$$

となりこれらの $\propto$ および $1 / \gamma$ の值は Fig. 7 では D 点に相当する。擋拌速度を 800 r. p. m. K增加する とき, $R / V$ は $1.53 \times 10^{-6}[\mathrm{~g} \cdot \mathrm{moles} / \mathrm{l} \cdot \mathrm{min}]$ となり,

Fig. 5 では $E$ 点に当たる。1/r の値を推算すれば, 143 となり Fig. 7 では E 点に当たる。Fig. 7 曲線（2）は $\alpha v=139$ で $1 / r \rightarrow \infty$ のとき $\Psi$ が極限值 $\Psi_{\max }=139 \mathrm{~K}$ 近つくことを示しており，D扰よび $\mathrm{E}$ 点の $\Psi$ の值 $\Psi_{D}$, $\Psi_{E}$ がなお $\Psi_{\max }$ よりかなり小であることから，搪散 および化学反応の両抵抗支配の範围にあることがわか る。また Fig. 5 曲線（1）の勾配ははぼ 0.23 で (29) 式による推算値 0.294 より小である*。このように総括 反応速度は擋拌速度の增加とともに大となるが桩散抵抗 支配の場合に予期されるほどにその增加割合は大でな W。

なお Fig. 7 曲線 (2) において $\Psi_{\max }=139$ で化学反 応律速の状態に達して総括反応速度は最大值 $R_{\max }$ に なるが，この場合 (21) 式は

$$
R_{\max }=\left(k_{w} D_{f}\right)^{1 / 2} A C_{\mathrm{s}} \Psi_{\max }=\left(k_{w} D_{f}\right)^{1 / 2} A C_{s}(139)
$$

と書き換えられ，要移的飽和度 $\Phi=1$ に等しい。また， Fig. 7 の D点机ける $\Psi$ の值は $\Psi_{D}$ は 60.2 である から,

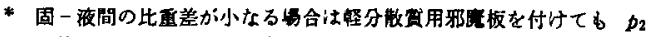
の值ははとんど率らないい。

** $d_{p}$ かi $0.079 \mathrm{~mm}$ と細な結晶の溶解速度の测定は困雉であるか ら,この武料の溶解速度の测定值から推算する。
}

$$
R_{D}=\left(k_{w} D_{f}\right)^{1 / 2} A C_{s} \Psi_{D}=\left(k_{w} D_{f}\right)^{1 / 2} A C_{s}(60.2)
$$

よって比 $R_{D} / R_{\max }$ の値は

$$
\underset{R_{\max }}{R_{D}}=\frac{\Psi_{D}}{\Psi_{\max }}=\frac{60.2}{139}=0.432
$$

となる。一方（17）式によれば

$$
\begin{gathered}
R_{D}=k_{w} C_{L} V=k_{w} C_{\mathrm{s}} V \Phi \\
R_{\max }=k_{w} C_{\mathrm{v}} V
\end{gathered}
$$

と表わされるから比 $R_{D} / R_{\max }$ は $\Phi$ に等しいことがわ かる。よって次の関係が得られる。

$$
\stackrel{R_{D}}{R_{\mathrm{max}}}=\frac{\Psi_{D}}{\Psi_{\max }}=\frac{C_{L}}{C_{s}}=\Phi
$$

Fig. 5 をみれば D点の $\Phi$ の値は $\Phi_{D}=0.415$ と与えら れ(右緃軸参照)，(35）式に批ける 0.432 とよく致し ている。同粎に $\Psi_{E}$ の值は Fig. 7 からは 69.0 と与兄 られるから比 $\Psi_{E} / \Psi_{\max }=69.0 / 139=0.497$ で Fig. 5 に拈ける $\Phi_{E}=0.505$ とよく一致している。

以上のことく $\Psi$ の值が総括反応速度 $(R / V)$ に比例 し，また総括反応速度に及ぼす摚拌の奻果を示す值とな ることが示された。

次に反応抵抗支配にきわ近い場合の例として，粒 径 35 45 mesh の無水安息香酸 $2.00 \mathrm{~g}$ を用いた結果に つき考察してみよ5。 $N=300$ r. p.m. に対して， $R / V$ $=2.57 \times 10^{-6}[\mathrm{~g} \cdot \mathrm{moles} / l \cdot \mathrm{min}]$ と測定され，これは Fig. 5, B 点で示される。 $\alpha v$ の推算値は 22.8 である。 $1 / r$ の值はフェール酢酸 $\left(\rho_{8}=1.21, d_{p}=0.762 \mathrm{~mm}\right)$ の溶解 速度の測定值から推算すれば 291 となりこれらの值は Fig. 7 では F 点に当たる。 $N=750$ r.p. m. と增加すれ ば $R / V=2.45 \times 10^{-6}[\mathrm{~g} \cdot \mathrm{moles} / l \cdot \mathrm{min}]$ となり，これは Fig. 5 ではC 点で示され，1/厅 の推算値は 396 となる。 これらの值は Fig. 7 では G 点に当たり，この点の $\Psi$ の値は $\Psi_{\max }$ に近い。これらの結果から化学反応が律 速段階となる状態に近い場合には擋拌の効果は著しく小 になること，また総括反応速度が極限值に近ついて，も はやそれ以上擋拌を強化しても無意味となる限界が存在 することが明らがされたわけである。

\section{3 化学反応抵抗支配の場合 ((b) および (c) の場} 合） Fig. 4 K括ける曲線（5）は粒径 180 200 mesh

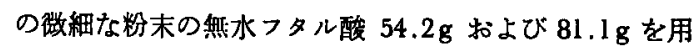
いて $a v=1$ の条件を满たした場合の $R / V$ の実测值で ある。摚拌速度扎よび投入量が著しく異なるにもかかわ らず反応速度は変化していない。このよ5な状態は （26）あるいは（27）式が適用される（b）または（c）の 昜合である。

$1 / r$ の值をこの無水フタル酸の試料 $\left(p_{s}=1.46\right)$ と比 重が注添等しい矹酸の結晶 $\left(p_{0}=1.47 \mathrm{~g} / \mathrm{cm}^{3}\right)$ が粒径 $d_{p}$ $=0.23 \mathrm{~mm}(60 \sim 100 \mathrm{mesh})$ の試料**の溶解速度の測定 
値から推算してみると，

$$
\begin{aligned}
x= & -D_{j B} \\
K & =D_{f B} /\left(\frac{R / V}{C_{A} A_{B} / V}\right) \\
= & 1.12 \times 10^{-5} /\left(\begin{array}{c}
16.3 / 1000 \times 60 \\
57.3 \times 10^{-3} \times 355 / 785
\end{array}\right) \\
= & 1.07 \times 10^{-s} \quad[\mathrm{~cm}] \\
\therefore \quad 1 / \gamma & =1 /\left(k_{w} x^{2} / D_{f}\right)^{1 / 2} \\
& =1 /\left\{(0.598 / 60)\left(1.07 \times 10^{-3}\right)^{2} / 7.75 \times 10^{-6}\right\} \\
& =26.1
\end{aligned}
$$

となる。これらの値は Fig. 7 の A 点で示され, 完全 な反応律速の範囲にあることを示す。

無水フタル酸で $\alpha v=1$ の状態を実現するにはこのよ 5にきわめて多量を用いなければならないがこれより $k_{w}$ の値が小なる無水安息香酸を用いると少量でこの状 熊が実現される。Fig. 5 点 A は 45 60 mesh の試料で 投入量 $4.00 \mathrm{~g}, N=300 \mathrm{r}$. p. m. としたと学の結果を示

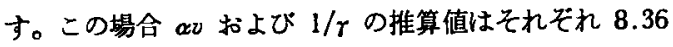
拈よび291 で Fig. 7 では H 点に当たる。 $\Psi$ の值がは ぼ $\Psi_{\max }$ に近いからほぼ反応抵抗支配に達していること がわかる。ことき $R / V=3.00 \times 10^{-6}[\mathrm{~g} \cdot \mathrm{moles} / l \cdot \mathrm{min}]$ で最大值である。

ここで他の条件をすへて一定として $N=800$ r. p. m. に增加すれば， $1 / r$ の值は381 となり，これは Fig.7 では I 点に当たる。同一試料で $\alpha v=1$ の場合を実現す るには，33g を用いて .4を8.36倍にすればよい。この 場合は Fig.7では J点で示される。

\section{8. 結 論}

（1）固一液系の反応を反応物質の物理的拡散の抵抗
々化学反応そのものの抵抗との大きさの比によって， (a) 払散律速，（b）反応抵抗々払散抵抗とが対比的,

（c）化学反応律速の場合の 3 つに大別した。

（2）無水フタル酸と無水安息香酸の結晶が水に溶解 して引続き加水分解する総括の反応速度（異相采反応） 々加水分解そのものの速度 (均一系反応) および液本体 に溶解した末反応の酸無水物の量を测定した。

（3）化学反応の速度があまり大でない場合は拡散境 膜内で反応する量が全反応量に比へて小であるから総括 反応速度は注注反応物質の液本体中に淤ける濃度に比例 することになる。この濃度が夜本体中で飽和値に達する までは哯拌速度によって総括反応速度が变化する。この 濃度とその飽和值との比を裂移的飽和度 $(\Phi)$ と名づけ た。のの值は異相系反応に扣ける檔拌の効果を示す一 つの尺度で，Фがにに近ければむはやそれ以上擋拌を 強化しても無意味であることがわかる。

（4）総括反応速度と摚拌強度との関保を示寸理論式 を導き，摚拌反応俰数 $\Psi$ を定義した。これによって異 相采の液相反応における必要な擋拌強度が決定される。

（5）理論と実験との一致を示し，また固一夜系の物 質移動に反応を伴なら場合でる拡散抵抗支配に近い場合 は物理的払散のみの物質移動に準して取り扱ってよいこ とを示した。

付記 実験に使用した無水フタル酸は日本触媒化学 工業株式会社より寄贈されたものである。実験にあたり 当教室原田誠君の協力る得た。付記して㳭甚なる謝意を 表する炊第である。

Nomenclature

$A$ : Total interfacial area

$\left[\mathrm{cm}^{2}\right]$

$b$ : Width of the impeller blades

$[\mathrm{cm}]$

$C$ : Concentration of reactant in solution [g.moles $/ l]$

$C^{\prime}$ : Concentration of reaction product in the solution after separation from the solid

$$
\text { [g. moles } / l]
$$

$C^{\prime}{ }_{\text {eq }}$ : Concentration of reaction product in the separated solution after an infinite time has elapsed

[g. moles $/ l]$

$C_{L}$ : Concentration of reactant in the liquid bulk

$[\mathrm{g} \cdot \mathrm{moles} / \mathrm{l}]$

$C_{P}$ : Concentration of reaction product in the liquid bulk

$[\mathrm{g} \cdot \mathrm{moles} / \mathrm{l}]$

$C_{S}$ : Concentration of reartant at saturation

\section{with reactant}

$[\mathrm{g} \cdot \mathrm{moles} / l]$

$C_{v}$ : Concentration of water

$[\mathrm{g} \cdot \mathrm{moles} / \mathrm{l}]$

$d$ : Diameter of the impeller

[cm]

$d_{p}$ : Equivalent particle diameter, calculated from the sphere of equivalent weight

[mm] or $[\mathrm{cm}]$

$D$ : Diameter of the agitation vessel $[\mathrm{cm}]$

$D_{f}$ : Diffusion coefficient of solute $\left[\mathrm{cm}^{2} / \mathrm{ser}\right]$

$g$ : Acceleration due to gravity $\left[\mathrm{cm} / \mathrm{sec}^{2}\right]$

$H_{l}$ : Liquid depth [cm]

$H_{p}$. Elevation of the impeller [cm]

$I$ : An integration constant [-]

$k$ : Hydrolysis reaction rate constant for 2 nd order reaction

$[l / \mathrm{g} \cdot \mathrm{moles} \cdot \mathrm{min}]$

$k_{w}=k C_{w}$ 


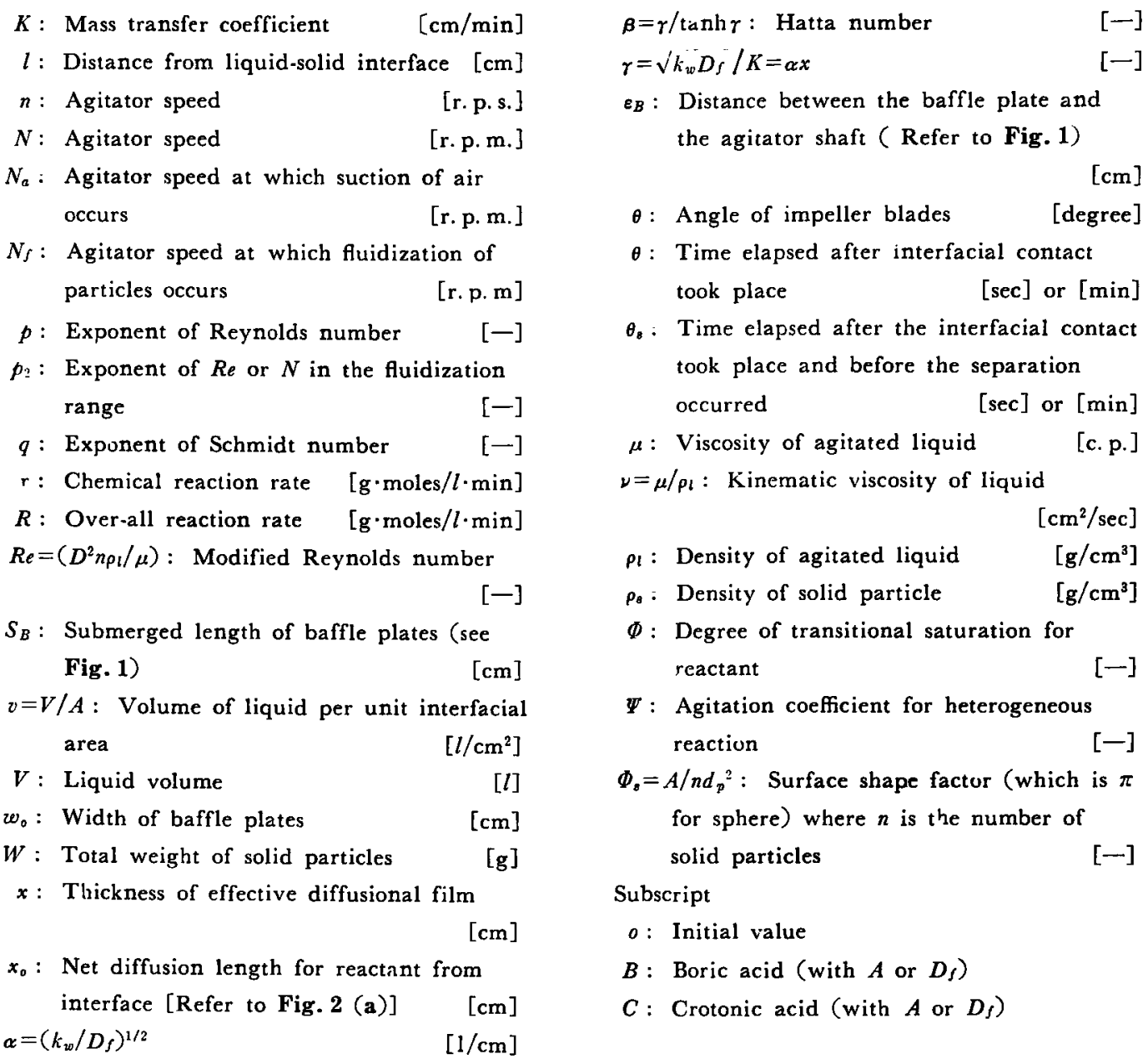

\section{Literatures cited}

1) Hatta, S.: Techn. Rep. Tohoku Imp. Univ., 10,613 (1932) or Sherwood, T. K. and Pigford, R. L.: "Absorption and extraction," McGraw.Hill Book Co., Inc., 2 nd Ed. p. 317 (1952)

2) Nagata, S., et al. . Chem. Eng. (Japan), 15,49 (1951)

3) Nagata, S., Yamaguchi, I., et al.: Chem. Eng. (Japan)
24, 618 (1960)

4) Nagata, S., Yamaguchi, I., et al. . Chent. Eng. (Japan) 24. 627 (1960)

5) Othemer, D. F. and Thaker, M. S. - I. E. C. 45,589 (1953)

6) Wilke, C. R. . Chem. Eng. Progress, 45.218 (1949) 


\title{
Effect of Agitation for Mass Transfer in Liquid-Solid Heterogeneous Reaction Systems
}

\author{
S. Nagata* and I. Yamaguchi*
}

In this paper, the authors deal with the dissolution of acid anhydride in water followed by the hydrolysis reaction.

Classification may be made of the types of reaction taking place, depending upon the relative rates of diffusion and hydrolysis of the acid anhydride.

(1) Diffusion resistance is controlling and the over-all rate of reaction depends only on the rate of solution. In this case the higher the agitator speed, the larger the rate of solution.

(2) Diffusion resistance and the chemical resistance to hydrolysis are comparable in magnitude. In this case the over-all rate of reaction depends not only on the agitator speed, but also on the rate of hydrolysis.

(3) Chemical resistance to hydrolysis is controlling and the over-all rate of reaction is independent of the agitator speed.

The authors derived the generalized rate equation and demonstrated the three types of reaction by the hydrolysis reaction of phthalic acid anhydride and benzoic acid anhydride suspended in water under agitation.

The authors propose the idea of the "degree of transitional saturation" and the "agitation coefficient for heterogeneous reaction"

The latter is useful for the determination of the available agitation intensity for heterogeneous liquid phase reactions.

* Department of Chem. Eng., Kyoto Univ., Japan 